\title{
AS INFLUÊNCIAS DO DIREITO ROMANO NA REGULAMENTAÇÃO DA HIPOTECA NO \\ BRASIL
}

\author{
Maria Vital da Rocha \\ Pós Doutoranda em Direito, na Faculdade de Direito da \\ Universidade de Lisboa. Professora Adjunta de Direito \\ Civil, na Faculdade de Direito da Universidade Federal do \\ Ceará. Professora Titular do curso de graduação em \\ Direito do Centro Universitário 7 de Setembro - UNI7. \\ mavital@secrel.com.br

\begin{abstract}
Marfisa Oliveira Cacau
Mestranda no Centro Universitário 7 de Setembro - UNI7. Especialista em Direito de Tributário pela Fundação Getúlio Vargas, Rio de Janeiro. Advogada. marfisacacau@gmail.com
\end{abstract}

\begin{abstract}
RESUMO: Este artigo tem a pretensão de promover o estudo da hipoteca no direito romano e no direito brasileiro, a fim de perceber a influência de Roma na normatização do tema no Brasil. Para tanto, utilizar-se-ão os métodos dedutivo e comparativo. Incialmente, far-se-á a exposição de conceitos propedêuticos básicos para a compreensão da hipoteca, enquanto direito real de garantia. Posteriormente, será abordada a hipoteca no direito romano. Em seguida, analisarse-á o tratamento da hipoteca no Brasil e os influxos que sofreu da tradição romanista. Ao fim, concluir-se-á que o Brasil se inspirou no direito romano naquilo que foi essencial para estimular a segurança da instituição do crédito hipotecário: aproximou-se da legislação romana no que esta tinha de louvável e se afastou no que fosse criticável.
\end{abstract}

PALAVRAS-CHAVE: Hipoteca. Garantia hipotecária. Direito Romano. Direito brasileiro.

\section{The influences of the Roman Law on the mortgage regulation in Brazil}

\begin{abstract}
This article intends to promote the study of mortgages in Roman law and Brazilian law, in order to understand the influence of Rome in the normatization of the subject in Brazil. For that, the deductive and comparative methods will be used. Initially, it will be exposed the basic propaedeutic concepts for the understanding of the mortgage, as a real estate security interest. Subsequently, it will be addressed the mortgage will in Roman law. Next, it will be analyzed the mortgage treatment in Brazil and the inflows that it suffered from the Romanist tradition. In the end, it will be concluded that Brazil was inspired by Roman law in what was essential to stimulate the security of the institution of the mortgage credit: it approached the Roman legislation in what it had of praiseworthy and moved away in what could be criticized.
\end{abstract}

KEYWORDS: Mortgage. Security interest. Roman Law. Brazilian Law.

\section{INTRODUÇÃO}

A hipoteca é um instituto milenar destinado a garantir o pagamento de um débito pelo devedor. Teve uma importância muito grande no desenvolvimento do sistema registral brasilei- 
ro e também das instituições financeiras, já que, nos primórdios, era o meio preferido pelos credores para garantir as suas dívidas. Contudo, mais recentemente, a garantia hipotecária perdeu a predileção de outrora ${ }^{1}$ e, em seu lugar, enquanto instrumento de garantia preferido dos credores, ganhou proeminência o instituto de alienação fiduciária (SANTOS, 2006, p. 167)

Com efeito, a alienação fiduciária possui algumas vantagens frente à hipoteca, que não passou despercebida pelos detentores do capital privado. A primeira é que a excussão do bem e a consolidação da sua propriedade em nome do credor é facilitada mediante um procedimento extrajudicial que se processa perante o Registro de Imóveis. Essa benesse não existe no caso da hipoteca, em que o credor deve necessariamente fazer uso do Poder Judiciário para executar o bem hipotecado, em caso de inadimplemento do devedor. $\mathrm{O}$ segundo trunfo da alienação fiduciária é a constituição de um patrimônio de afetação, por meio do qual é transferida a propriedade resolúvel do bem ao credor, de maneira que o objeto da garantia não será atingido em caso de insolvência de qualquer das partes, seja do credor, seja do devedor. Por outro lado, caso venha a falir o devedor hipotecário, o bem integrará necessariamente o concurso universal de credores, observada a ordem legal de preferência estabelecida na Lei 11.101/2005.

Não obstante essas interessantes características da alienação fiduciária em garantia, ela possui um grande defeito, que contradiz aos interesses dos bancos públicos - os quais têm preferido a garantia hipotecária em detrimento da fiduciária. Essa deficiência consiste no fato de o credor fiduciário exonerar o devedor após o segundo leilão extrajudicial, independentemente do valor auferido nesse procedimento, que pode ser inclusive inferior ao valor da dívida. Explique-se: na alienação fiduciária, após consolidado o bem nas mãos do devedor (o que é feito mediante o procedimento extrajudicial perante o Oficial de Registro de Imóveis, conforme artigo 26 e parágrafos da Lei 9.514/1997), e infrutífero o primeiro leilão extrajudicial, será realizado o segundo leilão, e a dívida se considera extinta ainda que o valor auferido seja inferior ao valor da dívida, das despesas, dos prêmios de seguro, dos encargos legais e das contribuições condominiais (artigo 27, $\S \S 5^{\circ}$ e $6^{\circ}$ da Lei 9.514/1997). Nessa situação, dá-se a exoneração do devedor, mesmo que o valor recebido pelo credor seja menor do que o devido. Em contrapartida, no caso da hipoteca, uma vez realizada a excussão do bem hipotecado, caso o valor obtido com a venda não seja suficiente para o pagamento das dívidas e despesas judiciais, o devedor continua vinculado pessoalmente ao pagamento do remanescente (artigo 1430, Código Civil de 2002).

Diante disso, percebe-se que a exoneração do devedor após a excussão do bem na alienação fiduciária é seu principal inconveniente, o que faz com que os bancos públicos prefiram a hipoteca como meio de garantir as suas dívidas. Isso por que, nesse caso, o devedor permanecerá sujeito à dívida até a sua quitação integral - ainda que o valor do bem afetado a garantia não seja suficiente para seu pagamento. Como o patrimônio público é indisponível (princípio da indisponibilidade do interesse público), não podem os bancos estatais transigir sobre o valor que irão receber de seus devedores, o que acabaria por ocorrer caso optassem por constituir a propriedade fiduciária em detrimento da garantia hipotecária.

Demonstrada a importância da hipoteca nos dias atuais, este artigo se propõe a analisar as influências do direito romano no desenvolvimento desse instituto no direito civil brasileiro. Para tanto, por meio do método de abordagem o dedutivo e como método auxiliar o comparativo, será feita uma exposição introdutória acerca da propriedade e dos direitos reais de garantia,

1 Nessa linha, salienta Francisco Claudio de Almeida dos Santos (2006, p. 167) que: “A hipoteca teve grande importância no desenvolvimento do crédito rural entre nós, bem assim na criação do mercado de crédito destinado à habitação. Créditos mais aquinhoados em privilégios, como o crédito fiscal e trabalhista, bem como a lentidão na solução de controvérsias submetidas ao Judiciário, provocaram o desprestígio dessa garantia, substituída pela alienação em garantia". 
e, posteriormente, adentrar-se-á no estudo da hipoteca em Roma e no Brasil, para ao final concluir a exposição com destaque dos pontos em que a normatização brasileira se aproxima ou não da romana.

\section{Propriedade E DiReitos Reais de GaRantia: NOÇõeS PRELIMINARES}

\subsection{Propriedade}

O direito romano, conforme leciona Ronaldo Poletti (1996, p. 106), não conceituou diretamente a propriedade. Na realidade, a definição da propriedade era feita de modo indireto, por meio de seus atributos, quais sejam: o jus fruendi, o jus abutendi e o jus utendi. Referem-se eles, respectivamente, aos direitos atribuídos ao proprietário da coisa de: colher os frutos e produtos da coisa; consumir a coisa ou dela dispor, seja por meio da alienação ou destruição; e de usar a coisa como lhe aprouver.

O conceito de propriedade foi melhor desenvolvido na Idade Média, por meio da análise dos escritos romanos. Nesse sentido, Ronaldo Poletti (1996, p. 106) cita José Carlos Moreira Alves para ensinar que:

[...] com base num escrito de Constantino (C. IV., 35, 21), relativo à gestão de ne-
gócios, definiram o proprietário como "suae rei moderator et arbiter" (regente e ár-
bitro de sua coisa); de fragmento do Digesto (V, $3,25,11$ ), sobre o possuidor de
boa-fé, deduziram que a propriedade seria o "ius utendi et abutendi re sua" (direito
de usar e de abusar da sua coisa); e de outra lei do Digesto (I, 5, pr.), em que se de-
fine a liberdade, resultou a aplicação desse conceito à propriedade que, então, seria
a "naturalis in re facultas eius quod cuique facere libet, nisi si quid aut vi aut iure
prohibetur" (faculdade natural de se fazer o que se quiser sobre a coisa, exceto
aquilo que é vedado pela força ou pelo direito).

Sob a égide do Código Civil de 1916, Pontes de Miranda, defendia que a propriedade poderia ser conceituada em sentido amplíssimo, amplo e estritíssimo. Assevera que, em sentido amplíssimo, a "propriedade é o domínio ou qualquer direito patrimonial. [...] Em sentido amplo, propriedade é todo direito irradiado em virtude de ter incidido regra de direito das coisas [...]. E sentido estritíssimo, é só o domínio".

Da exposição desses conceitos, percebe-se que não há uma distinção clara quanto aos conceitos de propriedade e domínio, por vezes expostos como sinônimos. Nesse ponto, convém trazer a doutrina de Cristiano Chaves de Farias e Nelson Rosenvald - com a qual se concorda. Esses, fundados em Ricardo Aronne, distinguem a propriedade do domínio. Entendem que, enquanto o domínio seria a "relação material de submissão direta e imediata da coisa ao poder de seu titular, através do exercício das faculdades de uso, gozo e disposição" - a semelhança do jus fruendi, o jus abutendi e o jus utendi do direito romano - a propriedade seria uma "relação jurídica complexa formada entre o titular do bem e a coletividade de pessoas". E arrematam:

Quanto a natureza de seu conteúdo, o domínio é um direito real que se exerce através da posse. O proprietário exercita ingerência sobre a coisa (domínio) e pede a colaboração de pessoas (propriedade). Somente na propriedade plena é possível observar que o direito de propriedade e todos os poderes do domínio se concentram em uma só pessoa. 
Essa diferenciação é importante para compreender que é viável que haja um desmembramento dos poderes inerentes ao domínio, sem que a propriedade seja afetada. Essa possibilidade é referenciada pelo princípio da elasticidade ou expansão potencial da propriedade (MIRANDA, 2012, p. 37). Sendo assim, dá-se a propriedade plena quando todos esses poderes estiverem nas mãos do titular da propriedade. Por outro lado, o proprietário do bem poderá efetuar o fracionamento dos poderes de usar, gozar e dispor e atribuí-los a distintas pessoas. É justamente nessa elasticidade que se fundamentam os direitos reais sobre coisa alheia.

\subsection{Direitos reais de garantia}

Os direitos reais são divididos, no direito romano, em duas espécies: direitos reais sobre coisa própria (ius in re propria) e direitos reais sobre coisa alheia (ius in re aliena). É dentro do ius in re aliena que se inserem os direitos reais de garantia.

A doutrina aponta que, em Roma, havia basicamente três espécies de direitos reais de garantia: alienação fiduciária, penhor e hipoteca (TABOSA, 2007, p. 270). A alienação fiduciária (fiducia cum creditore) era o contrato, por meio do qual a propriedade do devedor era transferida ao credor, que, por sua vez, comprometia-se, de forma solene, perante o magistrado, a devolver o bem ao devedor tão logo esse efetuasse o pagamento da dívida (ROLIM, 2008, p. 214). O penhor (pignus datum) se caracterizava pela entrega da posse de um bem como garantia do pagamento de um débito, de maneira que, uma vez quitada a dívida, far-se-ia a restituição do bem ao devedor. Era um contrato não solene, que se perfectibilizava com a simples tradição (traditio) (SILVA, 2008, p. 210). Por fim, a hipoteca (pignus obligatum) era um contrato de garantia em que o devedor poderia afetar um bem específico ou a totalidade de seu patrimônio para o pagamento da dívida (SILVA, 2008, p. 211-212), embora mantivesse consigo a posse do bem ou patrimônio.

A criação dos direitos reais de garantia tem como pressuposto a evolução do princípio da responsabilidade patrimonial. Isso se deve por que, antes do desenvolvimento da ideia de que é o patrimônio do devedor que responde por suas dívidas, vigia em Roma a responsabilidade pessoal, na qual a garantia do pagamento do débito era a própria pessoa ou o seu corpo que, muitas vezes, poderia vir a ser escravizada. Com efeito, Francisco José de Almeida Prado Ferraz Costa Junior (2014) leciona que, na época da Lei das XII Tábuas, diante do inadimplemento do devedor, esse seria adjudicado ao credor, que teria duas opções: matá-lo ou vendê-lo como escravo para o estrangeiro. Ainda, na eventualidade de haver concurso de credores, esses poderiam esquartejar o corpo do devedor e dividi-lo entre si. Foi apenas no ano de 326 a.c., com o advento da Lex Paetelia Papiria, que se propagou a ideia da responsabilidade patrimonial (SANTOS, 2006, p. 59), conforme brocardo latino pecúnia credita bona debitoris, non corpus obnoxium esset. Não obstante, ainda persistia resquícios da responsabilidade pessoal, diante da possibilidade de o devedor ir à residência do credor pagar a sua dívida com trabalho.

Expostas essas noções introdutórias sobre a propriedade e os direitos reais na coisa alheia, convém adentrar no estudo da hipoteca em Roma.

\section{A Hipoteca no DiReito Romano}

A origem do instituto da hipoteca no direito romano é controversa. Moreira Alves (2012, p. 364) faz referência a essa discussão doutrinária. Segundo o autor, há aqueles que entendem que a hipoteca romana tem inspiração no direito grego, de onde teria advindo o ter- 
mo hyphoteca. Por outro lado, há os que defendem ser o nascedouro da hipoteca associado ao praedia subdita uel subsignata, que se refere aqueles bens que eram dados em garantia em favor do Estado ou do Município e que, acaso não fossem pagos, seriam alienados em favor do aerarium. $\mathrm{O}$ mencionado doutrinador, contudo, refuta ambas as teorias para concluir que a hipoteca tem origem no arrendamento de imóveis rurais. Esse também é o entendimento de Eduardo Volterra (1986, p. 441), para quem a hipoteca teria se iniciado com os arrendamentos rústico e depois estendida para qualquer tipo de coisa corpórea.

Independentemente da teoria que se adote, fato é que a hipoteca estava associada ao pignus ou penhor ${ }^{2}$. Esse, por sua vez, dividia-se em pignus datum ou datio pignoris, em que a posse do bem era transferida ao credor, e pignus conventum ou conventio pignoris, no qual a o devedor permanecia com a posse do bem. A distinção entre ambos, portanto, era basicamente quanto à tradição ou não do bem dado em garantia. Não havia diferenciação entre penhor e hipoteca no que se refere a natureza jurídica do bem, se móvel ou imóvel. Nesse sentido, Moreira Alves (2012, p. 362) assevera que:

\begin{abstract}
Ambos - penhor e hipoteca - se aplicavam, indistintamente, às coisas móveis e imóveis. Aliás, a semelhança desses dois institutos está retratada na própria designação que as fontes dão a eles: ao penhor, pignus datum; à hipoteca, pignus obligatum. Em ambas as expressões o substantivo é o mesmo (pignus); é o adjetivo que muda: datum ou obligatum. Só no direito justianeu é que se torna corrente, para o pignus obligatum (hipoteca) a denominação hypotheca.
\end{abstract}

A constituição do pignus obligatum, portanto, dava-se tão somente com a própria convenção ${ }^{3}$. Não havia nenhuma formalidade excepcional para que a hipoteca se perfectibilizasse que não fosse o mero acordo de vontade entre as partes. De fato, segundo Eduardo Volterra (1986, p. 441), esse direito hipotecário "se constituye basándose en el simple acuerdo de garantía entre el acreedor y el deudor, sin transmisión de lá cosa al primero". Nessa mesma linha, Francisco José de Almeida Prado Ferraz Costa Junior (2014, p. 22) diz que a hipoteca era um "contrato de forma livre, admitindo inclusive a forma verbal, embora fosse comum reduzi-lo a escrito, para comodidade da prova, podendo garantir obrigação atual ou futura, civil, honorária ou meramente natural, própria ou de terceiro".

Infere-se, portanto, que Roma não possuía um sistema registral que pudesse dar publicidade e segurança às transações hipotecárias ${ }^{4}$. A rigor, o sistema de publicidade registral teve

2 Para o jurisconsulto Marciano, a distinção entre penho e hipoteca era só de nome, praticamente. É o que se constata em D. 20,1,5,1, Marciano: inter pignus autem et hypothecam tantum nominis sonus differt.

3 Antonio Fernández de Buján (2012, p. 516) cita Ulpiano para ratificar a afirmação de que o pignus conventum se perfectibiliza pelo mero acordo de vontade das partes: “Así ULpiano en D. 13.7.1.pr.: ‘... se puede contraer el pignus por la mera convención...', y en D. 13.7.9.2: 'Llamamos en sentido propio prenda la que pasa al acreedor e hipoteca cuando no pasa al acreedor ni la posesión"”.

4 A origem da hipoteca moderna não está, portanto em Roma. De fato, Francisco Claudio de Almeida Santos (2006, p. 63), citando Wolff, expõe que: "Surgiu, no século XIII, no direito imobiliário, uma garantia chamada "Satzung", que era concretizada através de solenidade pública, vislumbrando-se aí o início do princípio da publicidade adotado pelo direito alemão. Esta é, segundo Wolff, a raiz da hipoteca moderna”.

Essa afirmação é ratificada por Antonio Fernández de Buján (2012, p. 522), para quem "Con la excepción de las hipotecas constituidas a favor del fisco, en las provincias orientales del Imperio, respect de las cuales se establecía la necesidad de inscriber en un Registro Público el nombre de los deudores y los datos identificativos de sus bienes, no se conoció en Derecho Romano el actual sistema de publicidad conforme al cual para la válida constitución de la hipoteca se require su inscripción en el Registro de la Propriedad".

Ao contrário dos outros autores citados nas notas de rodapé acima, um texto de Chaplin (1891) não concorda com a referida afirmação e entende haver um ato notório na constituição da hipoteca seguida de sua respectiva inscrição no registro público. Diz o autor: "The Roman law made no material distinction, in matter of pledges, between land and chattels. The system was one and the same for a farm and for a cart. If a pledgee took possession, the transaction was a pawn; if not, it was a hypothecation. And to obviate embarrassments from the pledgor's retaining possession, 
sua origem na Grécia, e não em Roma, que teve apenas meros vislumbres episódicos dessa técnica. Não obstante, há quem visualize em Roma os primórdios do sistema publicitário. Nesse ponto, Francisco José de Almeida Prado Ferraz Costa Junior (2014, p. 22) relata que:

\begin{abstract}
A hipoteca no direito grego era dotada de um sistema de publicidade, ainda que primitivo, consistente na inscrição do ônus em pedras ou postes de madeira, chamados horói, que se colocavam nos limites dos prédios rústicos ou urbanos gravados, a fim de que terceiros pudessem tomar ciência de sua situação. Durante a dominação romana, Biondo Biondi relata ter sido desenvolvido nas províncias orientais um sistema de livros fundiários, nos quais se anotavam as transferências de domínio e os ônus que gravavam os imóveis. Uma constituição imperial de Leão (C $8,17,11)$ do ano 472 d.C., dispôs que, no concurso de credores hipotecários, teriam preferencia as hipotecas reduzidas a escrito, com expressa referencia àquelas constituídas perante um oficial público, constituição imperial esta que, para Ebert Chamoum é a origem remota de nosso sistema publicitário [...].
\end{abstract}

Apesar desse desenvolvimento incipiente de uma publicidade formal relatado pelo excerto acima, não possuía ela o condão de dar segurança jurídica às transações garantidas por hipoteca. Isso por que a hipoteca, como regra, recaia sobre todos os bens do devedor, presentes e futuros, sem uma individualização ou especialização ${ }^{5}$. Como não existia um registro público em que houvesse a concentração de todos os dados relativos ao imóvel, a fim de dar publicidade à terceiros, o devedor poderia se desfazer de todo o seu patrimônio, sem que o credor viesse a saber. Isso causava uma vulnerabilidade no sistema de garantia de débitos por meio da hipoteca, que, por conseguinte, ocasionou a sua não popularização em Roma. Com efeito, os romanos preferiam as garantias pessoais (tal como a fiança) em detrimento das garantias reais.

Moreira Alves (2012, p. 361) para aponta três falhas do sistema hipotecário romano que, por sua vez, contribuíram para a não propagação a hipoteca como meio de garantia dos débitos em Roma. São eles: a informalidade na constituição da garantia hipotecária, que poderia se dar por mera convenção entre as partes, até mesmo verbal; a falta de segurança jurídica diante da ausência de um sistema de publicidade registral; e a instabilidade gerada pela admissibilidade de instituição da hipoteca sobre todos os bens do devedor, e não um individualizado ${ }^{6}$.

Apesar da ausência de um sistema registral próprio, o direito romano conheceu a preferência creditória na possibilidade de instituição de diversas hipotecas sobre o mesmo bem. Nesse diapasão, o autor Esteban Varela Mateos (2000, p. 559-560) relata que Roma admitia a duplicidade de hipotecas sobre a mesma coisa. Como não havia um sistema de registros públicos que estabelecesse a prioridade da inscrição hipotecária, a eleição da preferência teria dois critérios: primeiramente, teria precedência aquele credor que tivesse a posse do pignus; não sendo este o caso, a prevalência recairia sobre aquele credor que detivesse o "melhor direito" embora o autor não relate no que consistiria esse melhor direito.

Contudo, não era sempre que se admitiria a constituição da segunda hipoteca - que era uma excepcionalidade do sistema. As situações que a abraçavam eram: quando o valor da coisa fosse superior ao da primeira hipoteca, o que permitiria dar segurança a ambas as garantias; e

and with it a show of ownership, it was quite early provided that a fully effective hypothecation could be made only by some notorious act recognized by law, as by registration in a public office.

5 Diz-se, em regra, pois, para Antonio Fernández de Buján (2012, p. 518), Roma admitia a hipoteca especial, em que se afetava um bem determinado à garantia da dívida, em algumas situações, tal como a do "acreedor refaccionario. Explica o doutrinador espanhol: "En cuanto a la hipoteca a favor del acreedor refaccionario, del latín refacio, reparar, rehacer, cabe señalar que es aquélla que se constituye a favor de quien presto dinero para la reparación de um edificio, y recae sobre el edificio reparado por el importe del crédito prestado. Así Ulpiano en D. 12.1.25: 'El acreedor que hubiese prestado para la refacción de um edificio tundra para la cantidad que hubiese prestado un privilegio de cobro"".

6 Esse entendimento é ratificado por Francisco Claudio Almeida dos Santos (2006, p. 62). 
sempre que o primeiro credor autorizasse a constituição da segunda hipoteca (MATEOS, 2000, p. 560). Nessa situação, o segundo credor hipotecário teria preferência em relação ao primeiro e seria assegurada a segurança do negócio, seja por que haveria valor suficiente para as duas garantias hipotecárias, seja em razão do consentimento dado pelo credor primitivo.

A hipoteca, portanto, deveria incidir sobre bem ou patrimônio do próprio devedor. Se, porventura, este concedesse coisa de outrem como garantia de dívida, poderia ser condenado pelo delito de estelionato, conforme relata Gumesindo Padilla Sahagún (2004, p. 103).

Independentemente da regra eleita quanto ao concurso creditório, inicialmente, Roma admitia que o credor hipotecário lesado em seu direito de reaver os recursos emprestados poderia ficar com a coisa objeto da garantia. É o que se convencionou chamar de pacto comissório, por meio do qual se aplicaria a pena de comisso, ou seja, que seria a "a perda de um direito ou de uma coisa". Assim, uma vez não paga a dívida, o imóvel poderia ser adjudicado ao credor hipotecário. Essa prerrogativa creditícia, contudo, veio a ser proibida no período pós-clássico, pelo Imperador Constantino.

Francisco Claudio de Almeida Santos (2006, p. 94) cita, em tradução livre, Trabucchi para explicar o fundamento dessa proibição: “[...] é de impedir que o devedor firme constrangido o pacto, que possui frequentemente caráter usurário, seja para obter o empréstimo, seja para obter dilação na obrigação de restituir". Dessa forma, caso fosse permitido o pacto comissório, via de regra, ele seria imposto pelo credor ao devedor que, desejoso de contratar o mútuo, aceitá-lo-ia sem maiores restrições. A fim de evitar o constrangimento nessa liberdade de contratar do devedor, proibiu-se a pena de comisso.

Essa vedação ao pacto comissório é sentida até os dias atuais nos países de tradição romano-germânica, tal como o Brasil. Por outro lado, nos países de influência anglo-saxã, tais como Inglaterra e Estados Unidos da América, admite-se que o credor adjudique o bem hipotecado em pagamento da dívida (SANTOS, 2006, p. 94).

Uma vez delineado esse panorama sobre a hipoteca em Roma, impende fazer a análise desse instituto no direito brasileiro, com foco nas aproximações e distanciamentos em relação ao direito romano.

\section{A HIPOTECA NO DIREITO BRASILEIRO E A INFLUÊNCIA ROMANA}

O desenvolvimento da hipoteca no Brasil está atrelado a criação de um sistema de registros, a fim de dar publicidade e segurança para a constituição desse ônus real e, por conseguinte, estimular a concessão de empréstimos que serviriam, ao fim, para movimentar a economia do país. Isso só veio a ocorrer 20 anos após a decretação da independência do Brasil, já que, durante o período colonial, não era interesse de Portugal que o Brasil se desenvolvesse economicamente, mas sim que continuasse a adquirir produtos de Portugal e de seus aliados, tal como a Inglaterra.

Sendo assim, a Lei Orçamentária 317/1843, regulamentada pelo Decreto 482/1846, criou o "Registro Hipotecário". Embora tenha deixado de fora todos os demais tipos de direitos reais, essa lei teve a intenção louvável de dar mais tranquilidade aos mutuantes, já que, antes da instituição desse registro, o devedor poderia fazer várias hipotecas, sem que um credor tivesse conhecimento do outro - o que gerava uma insegurança na garantia de empréstimos por meio da hipoteca. 
A influência do direito romano na elaboração desse registro é percebida em relação à três nuances: hipotecas gerais, direito de preferência e ausência da publicidade. De fato, nessa época, era possível que fosse constituída uma hipoteca sobre a totalidade do patrimônio do devedor, sem afetação de um bem específico à garantia da dívida. Dessa forma, nos primórdios, Brasil admitia a instituição de hipotecas gerais. Também já nesse momento se instituiu o direito de preferência no caso de multiplicidade de hipotecas sobre o mesmo bem: aquele que inscrevesse a hipoteca anteriormente, teria prioridade na excussão do bem hipotecado. Por fim, não havia a exigência de publicidade, tal como se conhece hodiernamente (SANTOS, 2006, p. 170).

Por outro lado, por meio da Lei 1.237/1865, a normatização brasileira já começa a se distanciar da romana. Com efeito, nessa época, criou-se um Registro Geral de Imóveis, situação em que o sistema de transmissão de imóveis se modificou da tradição (tal como ocorria no direito romano) para o registro (LAGO, 2016, p. 159).

Nessa mesma linha de se afastar das influências romanas, foi promulgado o Decreto 169-A, de 19.01.1890, por meio do qual extinguiu-se a possibilidade de instituição de hipoteca geral, que recairiam sobre todos os bens do devedor, e desenvolveram-se as ideias de especialização objetiva e da publicidade registral (SANTOS, 2006, p. 169-170), que persistem até os dias atuais como pilares do sistema de registros públicos brasileiro.

A regra da especialidade objetiva dispõe que deve haver uma perfeita individualização do objeto sujeito a registro: seja do bem imóvel, seja do direito real a ele relativo (LOUREIRO, 2017, p. 570). Essa individualização deve constar não apenas do registro, mas também do título que lhe deu origem (seja ele convencional ou judicial). Nessa linha, o artigo 1424 do Código Civil de 2002 estabelece expressamente os requisitos que o contrato de hipoteca deve conter a fim de obter a eficácia jurídica que pretende: o valor do crédito, sua estimação, ou valor máximo; o prazo fixado para pagamento; a taxa dos juros, se houver; o bem dado em garantia com as suas especificações.

Já o princípio da publicidade registral, por sua vez, conforme lição de Marcelo Salaroli de Oliveira (2010, p. 15), "consiste em assentos tecnicamente organizados, destinados a promover o conhecimento, a qualquer interessado, da situação jurídica dos bens imóveis, cujo efeito, no mínimo, é a presunção inatacável de conhecimento". Esse princípio está positivado no artigo 16 e 17 da Lei de Registros Públicos (Lei 6.015/73): incumbe ao oficial de registro lavrar certidão do que lhes for requerido e requerer às partes as informações solicitadas, e qualquer pessoa pode ter acesso aos dados constantes dos registros públicos, independentemente da demonstração de interesse jurídico.

Nesse ponto, convém trazer uma diferenciação feita por Marcelo Salaroli de Oliveira (2010, p. 13-14) baseado nos ensinamentos de Carlos Ferreira de Almeida sobre as espécies de publicidade:

\footnotetext{
A primeira, a publicidade notícia, é a que tem por finalidade apenas informar determinado ato, criando a presunção absoluta de seu conhecimento. A ausência da publicidade, e nesta hipótese, nenhum dano causa ao titular do direito. [...].

A publicidade declarativa é aquela imposta como condição de oponibilidade perante terceiros, ou seja, é requisito para a eficácia erga omnes. [...]

Por fim, a publicidade constitutiva é requisito essencial para a existência e validade dos atos jurídicos, que não tem eficácia sequer entre as partes contratantes sem a formalidade especial que os torna públicos.
}

Da análise desses conceitos, é de se inferir que a publicidade expressa nos 16 e 17 da Lei de Registros Públicos (Lei 6015/73) é apenas a modalidade "publicidade notícia", que tem 
como objetivo dar conhecimento do teor do registro. Ainda, somente a publicidade notícia e a publicidade declarativa se aplicam a hipoteca, já que o registro presume o conhecimento da garantia hipotecária e também é condição de oponibilidade perante terceiros. Portanto, não se aplica a publicidade constitutiva, já que, ainda que não seja feito o registro do título hipotecário, a garantia permanecerá válida entre as partes contratantes.

Exposto esse panorama histórico do sistema registral e do desenvolvimento dos princípios da especialidade e publicidade, é possível perceber que, no Brasil, a garantia hipotecária incide, como regra, sobre bens imóveis. Apenas de maneira excepcional é que se permite a instituição da garantia hipotecária sobre bens móveis, no que se convencionou denominar de "hipoteca especial". É o caso da hipoteca instituída sobre aeronaves e navios, que estão sujeitas a registros apartados do sistema de registros públicos da Lei 6.015/73. Sendo assim, enquanto a compra e venda e respectivos ônus reais incidentes sobre as aeronaves são registrados junto ao Registro Aeronáutico Brasileiro; aqueles relativos aos navios são objeto de registro no Tribunal Marítimo.

A garantia real que incide tipicamente sobre bens móveis, no ordenamento jurídico pátrio, é o penhor. Nesse ponto, convém salientar que há dois critérios utilizados pelo Código Civil para distinguir o penhor da hipoteca: a natureza e a tradição do bem. Portanto, o penhor recai sobre bens móveis cuja posse é transferida para o credor; já a hipoteca incide sobre bens imóveis cuja posse permanece nas mãos do devedor. Há, contudo, exceções quanto à regra da tradição no que se refere ao penhor: é possível que o bem permaneça na posse do devedor, sem prejuízo da caracterização dessa garantia real, tal como ocorre no penhor rural, industrial, mercantil e de veículos (artigo 1431, parágrafo único, Código Civil de 2002).

De tais noções, é viável concluir que o sistema brasileiro se distancia do romano no que se refere a diferenciação do penhor e da hipoteca quanto à natureza do bem, uma vez que, no Brasil, a hipoteca incide sobre bens imóveis e o penhor sobre bens móveis, e, no direito romano, tanto a garantia hipotecária como a pignoratícia podem recair sobre coisas móveis ou imóveis. Por outro lado, aproxima-se quanto à tradição da coisa, pois, no Brasil e em Roma, como regra, se a posse do bem é transferida ao credor, estar-se-á diante do penhor, e se a posse permanece com o devedor, configura-se a hipoteca.

Um outro elemento em que não se vê a influência romana é no já exposto sistema registral. Isso por que, ao contrário do direito romano, em que a constituição da hipoteca era feita sem formalidades (podia ser inclusive verbal) e não estava sujeita o registro, o Brasil contempla uma série de requisitos que devem ser atendidos a fim de se conferir a segurança jurídica necessária para esse negócio jurídico.

Primeiramente, será assinada uma escritura pública de constituição da hipoteca perante um notário público, a quem foi delegada a fé pública estatal. A dispensa dessa solenidade apenas é possível em duas situações: se o direito real for inferior a 30 (trinta) vezes o maior salário mínimo vigente no país (artigo 108 do Código Civil de 2002), considerada a avaliação da hipoteca conforme valor atribuído pelo fisco ${ }^{7}$; ou se houver lei expressamente dispensando a escri-

\footnotetext{
7 Esse é o atual entendimento do STJ, conforme REsp 1.099.480-MG. Sendo assim, para que verifique se o valor do bem é ou não inferior a trinta salários mínimos não se considera o valor declarado pelas partes, mas sim a atribuição valorativa feita pelo fisco. Nesse sentido, a seguinte ementa: "RECURSO ESPECIAL - PROCEDIMENTO DE DÚVIDA SUSCITADO PELO OFICIAL DO CARTÓRIO DE REGISTRO DE IMÓVEIS - DISCUSSÃO SOBRE A INTERPRETAÇÃO DO ART. 108 DO CC - PROCEDÊNCIA DA DÚVIDA NAS INSTÂNCIAS ORDINÁRIAS - ENTENDIMENTO PELA NECESSIDADE DE ESCRITURA PÚBLICA PARA REGISTRO DE CONTRATO DE COMPRA E VENDA DE IMÓVEL CUJO VALOR DA AVALIAÇÃO PELO FISCO FOI SUPERIOR A TRINTA SALÁRIOS MÍNIMOS, AINDA QUE O VALOR DO NEGÓÇO DECLARADO PELAS PARTES TENHA SIDO INFERIOR. INSURGÊNCIA DA EMPRESA REQUERENTE DO REGISTRO. Hipótese em
} 
tura pública. Dentre essas situações, especificamente no que se refere à garantia hipotecária, incluem-se as hipotecas firmadas por entidades pertencentes ao Sistema Financeiro Imobiliário $(\mathrm{SFI})^{8}{ }^{9}$.

A seguir, uma vez consolidado o título hipotecário (que poderá ser contrato, no caso da hipoteca convencional; título de crédito, se for hipoteca cedular; ou decisão judicial, na situação das hipotecas judicial ou legal, se, nesse último caso, o credor não preferir por constituir o título perante o notário público ${ }^{10}$ ), ele deverá ser levado à registro junto ao oficial de registro de imóvel competente. Esse oficial, por sua vez, procederá a qualificação registral, a fim de verificar se o título de constituição da hipoteca atende todos os comandos legais. Se a qualificação jurídica do título for positiva, procederá com o registro. Se negativa, o título será entregue ao apresentante juntamente com uma nota devolutiva em que serão expostas as exigências que devem ser atendidas a fim de tornar o título apto a registro.

que o Oficial do Cartório de Registro de Imóveis suscitou dúvida ao Poder Judiciário, referente à interpretação do art. 108 do CC. O oficial cartorário e a empresa requerente do registro divergem quanto ao valor a ser considerado para fins de incidência da regra legal em questão: para aquele, a escritura de compra e venda deve ser feita por instrumento público, já que o fisco municipal avaliou o imóvel em valor superior a 30 (trinta) salários mínimos; para esta, a escritura de compra e venda pode ser feita por instrumento particular, pois o valor do negócio declarado pelas partes no contrato foi inferior a 30 (trinta) salários mínimos. As instâncias ordinárias entenderam que o valor a ser considerado, para fins de aferição da necessidade de escritura pública no caso concreto, não deve ser aquele declarado pelas partes, mas o da avaliação realizada pelo fisco, destacadamente quando o propósito dos interessados e a finalidade precípua do instrumento é a transferência de propriedade do bem, e não apenas o de retratar uma mera transação. 1. A interpretação dada ao art. 108 do CC pelas instâncias ordinárias é mais consentânea com a finalidade da referida norma, que é justamente conferir maior segurança jurídica aos negócios que envolvem a transferência da titularidade de bens imóveis. 2. O art. 108 do CC se refere ao valor do imóvel, e não ao preço do negócio. Assim, havendo disparidade entre ambos, é aquele que deve ser levado em conta para efeito de aplicação da ressalva prevista na parte final desse dispositivo legal. 3. A avaliação feita pela Fazenda Pública para atribuição do valor venal do imóvel é baseada em critérios objetivos previstos em lei, refletindo, de forma muito mais consentânea com a realidade do mercado imobiliário, o verdadeiro valor do imóvel objeto do negócio. 4. Recurso especial desprovido." (STJ - REsp: 1099480 MG 2008/0230045-4, Relator: Ministro MARCO BUZZI, Data de Julgamento: 02/12/2014, T4 - QUARTA TURMA, Data de Publicação: DJe 25/05/2015)

8 É o que está previsto no artigo 38 da Lei 9.514/1997, que trata do Sistema Financeiro Imobiliário: “Art. 38. Os atos e contratos referidos nesta Lei ou resultantes da sua aplicação, mesmo aqueles que visem à constituição, transferência, modificação ou renúncia de direitos reais sobre imóveis, poderão ser celebrados por escritura pública ou por instrumento particular com efeitos de escritura pública.".

9 A outras situações previstas em lei em que a escritura pública pode ser dispensada. Citem-se os seguintes: art. 26 da Lei $n^{\circ}$ 6.766/1979, que trata da Lei do Parcelamento do Solo Urbano, por meio do qual os compromissos de compra e venda, as cessões e as promessas de cessão de loteamentos devidamente registrados podem ser feitos por meio de instrumento particular; o art. $7^{\circ}$ do Decreto Lei $2.375 / 1987$, que prevê a dispensa da escritura pública nos termos, contratos e títulos expedidos pelos entes federados destinados à instrumentalizar a alienação, concessão, arrecadação ou reconheicmento de domínio sobre terras públicas rurais; o art. $8^{\circ}$ da Lei 10.188/2001, que trata do arrendamento residencial, e prevê que os contratos de aquisição de imóveis pelo arrendador, as cessões de posse, as promessas de cessão, o contrato de transferência do direito de propriedade ou de domínio útil ao arrendatário podem ser celebrados por contrato particular, que terá força de escritura pública; e art. 48 da Lei 10.257/2001, conhecido como "Estatuto da Cidade", que assevera que os contratos de concessão de direito real de imóvies públicos dentro do âmbito de programas habitacionais de interesse social, desenvolvidos pela Administração pública, terão eficácia de escritura pública.

10 Tradicionalmente, entendia-se que a hipoteca legal deveria ser especializada perante o juiz de direito. Contudo, com o advento do Novo Código de Processo Civil, passou a existir a possibilidade de o trâmite da hipoteca legal se processar perante o Notário Público, em processo extrajudicial. Esse procedimento está previsto nos $\S \S 2^{\circ}$ e $3^{\circ}$ do artigo 703: “\$ $2^{\circ}$ A homologação do penhor legal poderá ser promovida pela via extrajudicial mediante requerimento, que conterá os requisitos previstos no $\S 1$ o deste artigo, do credor a notário de sua livre escolha. $§ 30$ Recebido o requerimento, o notário promoverá a notificação extrajudicial do devedor para, no prazo de 5 (cinco) dias, pagar o débito ou impugnar sua cobrança, alegando por escrito uma das causas previstas no art. 704, hipótese em que o procedimento será encaminhado ao juízo competente para decisão.”. Nesse ponto, convém salientar que, para Luiz Guilherme Loureiro (2017, p. 711), esse procedimento extrajudicial de especialização da hipoteca legal poderá ser adotado sempre que o interessado for capaz. 
Uma das questões que podem dar ensejo à devolução do título é justamente a previsão do pacto comissório, que, no Brasil, é expressamente proibido no tocante à hipoteca. Esse é um ponto de clara influência romana, especialmente do período pós-clássico. Nessa época, Constantino passou a proibir expressamente a pena de comisso, como forma de evitar um constrangimento na liberdade individual do mutuário, que se veria impelido a aceitar a referida cláusula com vistas a obter o empréstimo de que precisava.

A vedação ao pacto comissório, contudo, não impede que, após o vencimento da dívida, credor e devedor convencionem dar o bem hipotecado em dação em pagamento para o pagamento da dívida (artigo 1428 e parágrafo único do Código Civil de 2002). Para Francisco Claudio de Almeida dos Santos (2006, p. 97), a possibilidade de dação em pagamento após o vencimento da hipoteca é uma decorrência da característica da acessoriedade ${ }^{11}$ (princípio da gravitação jurídica), aplicável a esta garantia real. Isso por que, extinta a hipoteca, "[...] ainda assim, não se dá a extinção da dívida garantida, caso remanesça algum débito. Fosse o contrário, da extinção da obrigação principal naturalmente, decorreria a extinção da obrigação acessória".

Por fim, a influência romana também se faz sentir na possibilidade de inscrição de mais de uma hipoteca sobre o bem. A multiplicidade de hipotecas é expressamente admitida pelo artigo 1476 do Código Civil de 2002: "O dono do imóvel hipotecado pode constituir outra hipoteca sobre ele, mediante novo título, em favor do mesmo ou de outro credor”.

A Lei de Registros Públicos (Lei 6.015/73) mitiga a regra da preferência do direito com base na primeira prenotação no que se refere às múltiplas hipotecas. Isso por que, como regra, o direito real que prevalecerá é aquele que primeiro for prenotado junto ao oficial de registro de imóveis competente (que é aquele responsável pela circunscrição territorial em que se inserir o bem). No caso da hipoteca, contudo, o primeiro credor hipotecário possui uma benesse em face do segundo. De fato, conforme artigo $189^{12}$ da Lei 6.015/73, o título da segunda hipoteca que fizer referência expressa a existência de uma primeira hipoteca, e desde que esta ainda não conste da matrícula do imóvel, apenas será registrado após o decurso do prazo de 30 (trinta) dias se o título da primeira hipoteca não for apresentado para registro. Portanto, o primeiro credor hipotecário, ainda que apresente seu título para registro posteriormente ao segundo credor hipotecário, desde que o faça dentro dos 30 (trinta) dias subsequentes à prenotação do título da segunda hipoteca, ainda terá preferência creditória em face desta. Em não o fazendo, a segunda hipoteca terá preferência sobre a primeira.

Embora a legislação civilista não seja expressa, Francisco Claudio de Almeida dos Santos (2006, p. 184) informa que constituição de múltiplas e sucessivas hipotecas está condicionada ao valor do bem: é preciso que ele comporte o valor da garantia primitiva e das que se lhe seguirem. Essa conclusão advém da interpretação do artigo 171, $2^{\circ}$, II, que prevê como subespécie do crime de estelionato a modalidade de "alienação ou oneração fraudulenta de coisa própria", que, dentre outras, contempla a conduta de dar garantia coisa própria gravada de ônus em que se omita essa circunstância. Arremata o autor:

[...] por isso deve o devedor ou terceiro prestador da garantia declarar na escritura a existência de hipoteca anterior, independentemente de o fato ser facilmente consta-

\footnotetext{
${ }^{11}$ A característica da acessoriedade da hipoteca implica que a existência da garantia real está vinculada à do direito principal, de maneira que não se admite a transmissão isolada: a garantia deve ser necessariamente transmitida junto com o crédito.

12 “Art. 189 - Apresentado título de segunda hipoteca, com referência expressa à existência de outra anterior, o oficial, depois de prenotá-lo, aguardará durante 30 (trinta) dias que os interessados na primeira promovam a inscrição. Esgotado esse prazo, que correrá da data da prenotação, sem que seja apresentado o título anterior, o segundo será inscrito e obterá preferência sobre aquele."
} 
tado no Registro de Imóveis. O silêncio malicioso ou intencional, em face do registro, pode não caracterizar o crime, mas poderá ensejar um pleito de indenização por perdas e danos, caso o credor seja iludido na sua boa-fé. (SANTOS, 2006, p. 184)

Dessa exposição, é possível inferir que a normatização brasileira sobre as hipotecas múltiplas e sucessivas se afasta da romana em alguns aspectos: quanto à preferência, quanto aos requisitos e quanto à caracterização do estelionato.

Em relação ao primeiro ponto, no Brasil, terá prioridade aquele credor que prenotou o título desde que o credor anterior não apresente o título hipotecário para registro no prazo de 30 (trinta) dias. Por outro lado, em Roma, a preferência era dada ao credor que detivesse a posse do bem ou, não sendo esse o caso, àquele que possuísse o melhor direito.

Em referência ao segundo aspecto, de requisito para a instituição da segunda garantia hipotecária, percebe-se que, no Brasil, apenas é necessário que o bem hipotecado tenha valor suficiente para albergar todos os ônus que venham a incidir sobre o imóvel. Não há, portanto, a possibilidade, tal como em Roma, de que, ainda que o valor do bem não seja suficiente, a garantia hipotecária seja concedida no caso de anuência do credor primitivo. Com efeito, a legislação atual sequer contempla eventual anuência do credor antecessor quanto à na constituição das hipotecas futuras ${ }^{13}$.

Por fim, relativamente ao delito de estelionato, no Brasil, ele fica caracterizado quando for constituída uma segunda hipoteca sobre o bem do próprio devedor, que omitir a existência de uma primeira hipoteca. Já em Roma, o estelionato se configura quando o devedor oferece o bem de outrem em garantia da dívida.

\section{CONCLUSÃO}

A regulamentação da hipoteca no direito romano, e todas as inovações, características e imperfeições que foram destacadas acima, orientou o legislador brasileiro na normatização do tema.

Com efeito, percebe-se que o ordenamento jurídico brasileiro não foi imune à tradição romanista, especialmente nos aspectos em que esta foi louvável. É o caso, por exemplo, da proibição da pena de comisso, uma vez que a previsão da adjudicação do bem ao credor em caso de inadimplemento da dívida era considerada uma restrição liberdade dos indivíduos, e poderia representar um eventual obstáculo à contratação da garantia hipotecária. Também merece elogios a permissão para a instituição de uma multiplicidade de hipotecas sobre o mesmo bem, já que tal medida estimula a concessão de vários empréstimos e, por conseguinte, movimenta a economia.

Em contrapartida, naqueles aspectos em que a legislação romanista pecou, o Brasil tentou se afastar dela e criar uma regulamentação que superasse as críticas feitas ao direito romano. Nesse contexto, insere-se a criação de um registro de imóveis, que tem como objetivo concentrar todas as informações relativas ao bem imóvel, especialmente os ônus, a fim de lhes dar publicidade a terceiros. Isso viabilizou que os possíveis credores pudessem verificar antecipa-

\footnotetext{
${ }^{13}$ Nesse ponto, convém salientar que a legislação brasileira fulmina com nulidade eventual proibição contratual de alienação do bem hipotecado - muito embora seja possível convencionar o vencimento antecipado do crédito. É o que prevê o artigo 1475 e parágrafo único do Código Civil de 2002: “Art. 1.475. É nula a cláusula que proíbe ao proprietário alienar imóvel hipotecado. Parágrafo único. Pode convencionar-se que vencerá o crédito hipotecário, se o imóvel for alienado.".
} 
damente eventuais contingências sobre o bem e, por conseguinte, diminuir os riscos envolvidos nessas operações.

Por todo o exposto, infere-se a importância de se analisar o direito romano, não apenas pelo aspecto histórico, mas também para compreender a essência dos institutos adotados pelo direito brasileiro.

\section{REFERÊNCIAS}

ALVES, José Carlos Moreira. Direito Romano. 15. ed. Rio de Janeiro: Forense, 2012.

BUJÁN, Antonio Fernández de. Derecho Privado Romano. Madrid: Iustel, 2012.

CHALHUB, Melhim Namen. Negócio Fiduciário. 4. ed. Rio de Janeiro, Renovar, 2009.

CHAPLIN, H. W. Story of Mortgage Law. Harvard Law Review, v. 4, p. 1-13, 1891

COSTA JUNIOR, Francisco José de Almeida Prado Ferraz. As Garantias reais no direito romano. Revista de Direito Imobiliário, São Paulo, v. 37, n. 77, p. 13-29, jul./dez. 2014.

GRECO, Rogério. Código Penal: comentado. Niterói: Impetus, 2016.

FARIAS, Cristiano Chaves d. ROSENVALD. Nelson. Curso de direito civil: direitos reais. 12. ed. rev. ampl. e atual. Salvador: Ed. JusPodvm, 2016.

LAGO, Ivan Jacopetti do. A Lei 13.097 de 2015 e sua contribuição para a governança fundiária. Revista de Direito Imobiliário, São Paulo, v. 39, n. 81, p. 155-184, jul. a dez./2016

LOUREIRO, Luiz Guilherme. Registros públicos: teoria e prática. 8a. ed. Salvador: Editora Juspodvm, 2017.

MATEOS, ESTEBAN VARELA in VILLAR, Alfonso Murillo (Org.). ESTUDIOS de derecho romano en memoria de Benito M.a. Reimundo Yanes. 1a. ed. Burgos: Servicio de Publicaciones, Univerisdad de Burgos, 2000.

MIRANDA, Pontes de. Tratado de direito privado. São Paulo: Revista dos Tribunais, 2012.

SAHAGÚN, Gumesindo Padilla. Derecho romano. 3. ed. México: Mcgraw-Hill, 2004.

SANTOS, Francisco Claudio de Almeida. Direito do promitente comprador e direitos reais de garantia: penhor- hipoteca- anticrese. São Paulo: Revista dos Tribunais, 2006.

SILVA, Luís Antônio Vieira da. História interna do Direito Romano Privado até Justiniano. Brasília: Senado Federal - Conselho Editorial, 2008

ROLIM, Luiz Antonio. Instituições de direito romano. 3. ed. São Paulo: Revista Dos Tribunais, 2008.

OLIVEIRA, Marcelo Salaroli de. Publicidade Registral Imobiliária. São Paulo: Saraiva, 2010.

POLETTI, Ronaldo. Elementos de direito romano público e privado. Brasília: Brasília Jurídica, 1996. p. 106.

TABOSA, Agerson. Direito Romano. 3. Ed. Fortaleza, Fa7, 2007.

VOLTERRA, Eduardo. Instituciones de derecho privado romano. Madrid: Editora Civitas S.A., 1986.

Recebido em: 22 dez. 2017.

Aceito em: 25 mar. 2018. 